\title{
FINE STRUCTURAL DISTRIBUTION OF ACETYLCHOLINE RECEPTORS AT DEVELOPING MOUSE NEUROMUSCULAR JUNCTIONS ${ }^{1}$
}

\author{
JULIA A. MATTHEWS-BELLINGER AND MIRIAM M. SALPETER ${ }^{2}$
}

Section of Neurobiology and Behavior, Division of Biology, Cornell University, Ithaca, New York 14853

Received May 27, 1982; Revised October 25, 1982; Accepted October 29, 1982

\begin{abstract}
The distribution of acetylcholine receptors (AChRs) in neuromuscular junctions of embryonic and newborn mice (strain 129/ReJ) was examined on the fine structural level using $\left[{ }^{125} \mathrm{I}\right] \alpha$-bungarotoxin labeling and quantitative electron microscope autoradiography. Changes in junctional receptor site density were related to changes in the structure of the postjunctional membrane, in particular the differentiation of morphologically distinct regions of thickened membrane and the formation of junctional folds. The following sequence of development is described: (1) At the earliest age examined, embryonic day 16 of gestation (i.e., at approximately the time when junctional receptor accumulations are first detected), subneural receptor aggregates have poorly defined boundaries and seem to extend beyond the region of direct axonal or Schwann cell contact. At that time the subneural AChR site density is somewhat variable but averages $\sim 2000$ to $3000 \mathrm{sites} / \mu \mathrm{m}^{2}$, and the subneural muscle membrane shows discontinuous membrane specialization (membrane thickening plus a cytoplasmic amorphous layer). There seems to be no preferential labeling of contact regions rich in such specialization compared with those where membrane thickening was less obvious or absent. (2) By birth, junctional AChRs are strongly correlated with morphologically specialized membrane, at a constant density of $\sim 9000 / \mu \mathrm{m}^{2}$ (comparable to that in adult animals of this strain of mouse). During the first postnatal week, a large fraction of the primary cleft is covered by Schwann cell rather than axon terminal. Receptor-rich dense membrane and incipient junctional folds are found under axon terminals and, to a lesser extent, under Schwann cell extensions, but they are not seen beyond the edge of the "junctional complex." Coated vesicles are a prominent feature of the subjunctional sarcoplasm in neonatal junctions, and their number declines sharply during the first week. (3) Junctional folds differentiate mainly after the first postnatal week. Development of folds is associated with a 1.5- to 1.8-fold increase in length of specialized thickened membrane and a parallel increase in number of receptor sites per endplate. Since this is also a period of rapid overall endplate growth (Stcinbach, J. H. (1981) Dev. Biol. 84: 267-276) the total number of endplate receptors increases $>30$-fold during the maturation period following the first week while the concentration of receptors $/ \mu \mathrm{m}^{2}$ of thickened membrane remains constant.
\end{abstract}

Neuromuscular junctions on vertebrate twitch muscles display a unique synaptic fine structure. In the adult, the postjunctional membrane (pjm) has regularly spaced deep infoldings whose openings face the putative trans-

\footnotetext{
${ }^{1}$ This work was supported by National Institutes of Health Grant NS 09315. The authors wish to thank Dr. Ralph Loring, who helped in preparing the $\left[{ }^{125} \mathrm{I}\right] \alpha$-bungarotoxin and Dr. Gerald Fischbach, in whose laboratory one of the experiments was carried out. We also gratefully acknowledge the excellent technical assistance of Mrs. Maria Szabo. Portions of this study have been presented in partial fulfillment for a Ph.D. degree at Cornell University and at the Society for Neuroscience (Matthews-Bellinger and Salpter, 1979).

${ }^{2}$ To whom correspondence should be addressed at Section of Neurobiology and Behavior, W 113 Seeley Mudd Building, Cornell University, Ithaca, NY 14853.
}

mitter release sites (Birks, 1966; Padykula and Gauthier, 1970; Heuser et al., 1974). Acetylcholine receptors (AChRs) are primarily localized on the crests of these junctional folds at a local density of 15,000 to 25,000 AChRs $/ \mu \mathrm{m}^{2}$ of membrane (Fertuck and Salpeter, 1974a, 1976; ${ }^{3}$ Porter and Barnard, 1975; Matthews-Bellinger and Salpeter, 1978; Land et al., 1980). This localization coincides with a region of the membrane which is morphologically specialized (Ellisman et al., 1976; Fertuck and Salpeter, 1976; Rash et al., 1978) and resembles the

\footnotetext{
${ }^{3}$ The AChR site densities given in Fertuck and Salpeter (1976) were about $40 \%$ too high due to a systematic error in determining the specific activity of the $\left[{ }^{125} \mathrm{I}\right] \alpha$-bungarotoxin.
} 
postsynaptic density common at neuronal synapses. In contrast to this restricted AChR distribution, acetylcholinesterase is found uniformly along the entire postjunctional surface at densities of $\sim 2000$ to 3000 sites $/ \mu \mathrm{m}^{2}$ (Salpeter, 1967; Salpeter et al., 1972), most likely localized in the surface basal lamina (Hall and Kelly, 1971; Betz and Sakmann, 1973; McMahan et al., 1978). Thus the adult postjunctional structure is heterogeneous both fine structurally and in its molecular organization.

During development, the junction undergoes a prolonged period of physiological and morphological maturation, extending to several weeks after birth (see review by Dennis, 1981). Several light microscope studies have surveyed the changes in the distribution of AChRs on developing rat or chick muscle fibers during this period (Bevan and Steinbach, 1977; Burden, 1977; Braithwaite and Harris, 1979; Steinbach, 1981). Neuromuscular transmission is first detected in rat muscles on embryonic day 14 or 15 (Diamond and Miledi, 1962; Bennett and Pettigrew, 1974; Dennis et al., 1981). At this time, AChRs are distributed uniformly over the surface of the immature muscle cells at a density of several hundred AChRs $/ \mu \mathrm{m}^{2}$ (Bevan and Steinbach, 1977). These authors also showed that beginning on embryonic day 16 , AChRs accumulate at the region of nerve muscle contact, and the extrajunctional AChR density gradually approaches zero. In both rat and chick muscles, the receptors within the initial AChR aggregate differ from adult junctional receptors with respect to several biochemical and functional properties. Adult receptor characteristics are acquired asynchronously during a period of synaptic maturation which takes several weeks (Burden, 1977; Sakmann and Brenner, 1978; Fischbach and Schuetze, 1980; Michler and Sakmann, 1980; Reiness and Hall, 1981; Reiness and Weinberg, 1981). The ultrastructural correlates of these functional changes have not yet been fully explored. In the present study on prenatal and young postnatal mouse muscles, we related quantitative changes in receptor concentrations to fine structural changes of the pjm as postsynaptic dense membrane and junctional folds differentiate.

\section{Materials and Methods}

This study was done in parallel with an investigation of the AChR distribution in dystrophic animals (Matthews-Bellinger and Salpeter, 1979). Therefore, we used primarily mice of the inbred strain 129/ReJ (Jackson Laboratory, Bar Harbor, ME) in which murine dystrophy first arose (Michelson et al., 1955). All data presented here are from animals who were homozygous normal at the dystrophy allele. Several Swiss albino mice (Blue Spruce Farms, Altamont, NY) of various ages were also used for control experiments and for a preliminary investigation of an apparent strain difference which was noticed during this study.

Because animals of the 129/ReJ strain are poor breeders, timed matings were not attempted. Pregnant females were isolated and checked daily and birth dates were recorded. Postnatal ages are given from the birth date, day 0 (e.g., "1-day" animals are $24 \pm 12 \mathrm{hr}$ old). For one experiment, homozygous normal embryos were obtained from a pregnant female and their prenatal age $(\sim 16$ days in utero) was estimated from extcrnal physical characteristics (Theiler, 1972). A total of $22129 / \mathrm{ReJ}$ animals (five adults and 17 young animals ranging in age from embryonic day 16 to 2 weeks postpartum) were used in defining the distribution of the AChR during normal development.

Preparation of $\left.{ }^{125} I\right] \alpha$-bungarotoxin. $\alpha$-Bungarotoxin $(\alpha$-BTX) was purified, iodinated, and characterized in collaboration with Dr. Ralph Loring. The purification followed the method of Lee et al. (1972) with slight modification. Iodination was achieved by a mild lactoperoxidase-catalyzed reaction with carrier-free $\mathrm{Na}^{125} \mathrm{I}$ (New England Nuclear). These procedures and the methods for determination of the molar specific activity $( \pm 15 \%)$ were detailed previously (Matthews-Bellinger and Salpeter, 1978; Loring et al., 1982). Four separate preparations of $\left[{ }^{125} \mathrm{I}\right] \alpha-\mathrm{BTX}$, with specific activity up to $\sim 80 \mathrm{Ci} / \mathrm{mmol}$, were used for the experiments reported here.

Labeling with $L^{125} I J \alpha$-BTX after fixation. In most cases, we labeled muscles with $\left[{ }^{125} \mathrm{I}\right] \alpha$-BTX after mild prefixation, in order to best preserve neuromuscular fine structure while labeling in vitro. The prefixation method chosen to minimize interference with subsequent toxin binding was paraformaldehyde/lysine/metaperiodate (made fresh to final concentrations of 1 or $2 \%$ paraformaldehyde, $0.01 \mathrm{M}$ sodium metaperiodate, and $0.075 \mathrm{M}$ lysine $/ \mathrm{HCl}$, all in $0.037 \mathrm{~m}$ sodium phosphate buffer, $\mathrm{pH}$ 7.4 (McLean and Nakane, 1974)). The sludy was mainly performed on extensor digitorum longus (EDL) muscles, but soleus (SOL) muscles were also examined. The standard protocol for prefixation involved cardiac perfusion with cold fixative followed by immersion fixation of the muscles (or muscle pieces) for a total of 2.5 to $3.5 \mathrm{hr}$ on ice. Fixed tissue was then washed extensively in phosphate rinse buffer ( $>18 \mathrm{hr}$ total at 0 to $4^{\circ} \mathrm{C}$ ) to reduce nonspecific binding of the toxin. AChRs were then labeled to saturation by incubation in 0.3 to $0.4 \mathrm{M}\left[{ }^{125} \mathrm{I}\right] \alpha$ BTX for $1.5 \mathrm{hr}$ at room temperature, again followed by extensive washing ( $>18 \mathrm{hr}, 0$ to $4^{\circ} \mathrm{C}$ ) including two to three 30 -min washes in unlabeled $\alpha$-BTX to exchange nonspecifically bound iodinated toxin. Tissue blocks were postfixed in $1 \% \mathrm{OsO}_{4}$, stained en bloc in $2 \%$ aqueous uranyl acetate (1 to $2 \mathrm{hr}$ at room temperature), dehydrated, and embedded in Epon 812.

The specificity and magnitude of $\left[{ }^{125} \mathrm{I}\right] \alpha$-BTX binding after this mild prefixation was studied quantitatively with light and electron microscope autoradiography using a variety of adult and neonatal (2-day) muscles. To verify saturation under our labeling conditions, several blocks were pretreated with unlabeled $\alpha$-BTX $(0.4 \mu \mathrm{M})$ for $1.5 \mathrm{hr}$ prior to labeling with radioactive toxin as described above. Residual binding of $\left[{ }^{125} \mathrm{I}\right] \alpha$-BTX at either adult or neonatal junctions was never more than $5 \%$ of that seen without such pretreatment. Values determined for maximal binding of $\left[{ }^{125} \mathrm{I}\right] \alpha$-BTX at the neuromuscular junction after prefixation were comparable to values for maximal binding to fresh muscle labeled to saturation either in vivo or in vitro.

Labeling of adult muscles after prefixation resulted in slightly higher levels of autoradiographic background ( $\leq 2$-fold) over all tissue. Analysis of $\left[{ }^{125} \mathrm{I}\right] \alpha$-BTX binding 
by gamma counting confirmed that prefixed muscle had somewhat higher binding to nonendplate regions of the muscle than did unfixed tissue. This slight increase in background was insignificant for the junctional analyses reported here.

Electron microscope (EM) autoradiography. EM autoradiography was done by the flat substrate method of Salpeter and Bachmann (1964, 1972). The technique is described in detail by Salpeter (1981). We used pale gold sections $(1000 \pm 100 \AA$ thick by interferometry), Ilford L4 emulsions, and D-19 developer. With this system, the resolution, expressed as the half-distance (HD, i.e., the distance from a line source within which $50 \%$ of the grains fall), has been determined to be $850 \pm 120 \AA$ (Salpeter et al., 1977).

In order to facilitate judgments of the different mor- phological features examined, the contrast of autoradiograms was enhanced by "poststaining" after they were developed and placed on EM grids. All solutions were put out as large drops on a clean Teflon surface. The collodion substrate was first dissolved by immersing the grid in amyl acetate for 2.5 to $4 \mathrm{~min}$, followed by two rinses in absolute ethanol for a total of $\sim 1 \mathrm{~min}$, then a series of rapid rinses in drops of $95 \%, 70 \%, 50 \%$, and $25 \%$ ethanol, and finally several drops of distilled water. The grid was then dried completely; when dry, the grid was touched, section side down, for a few seconds to a drop of $2 \%$ aqueous uranyl acetate, then carefully washed and again dried completely. (This short exposure to uranyl acetate seems to stabilize the autoradiogram, preventing it from floating off the grid in the subsequent staining with lead.) Finally, grids were floated section side down
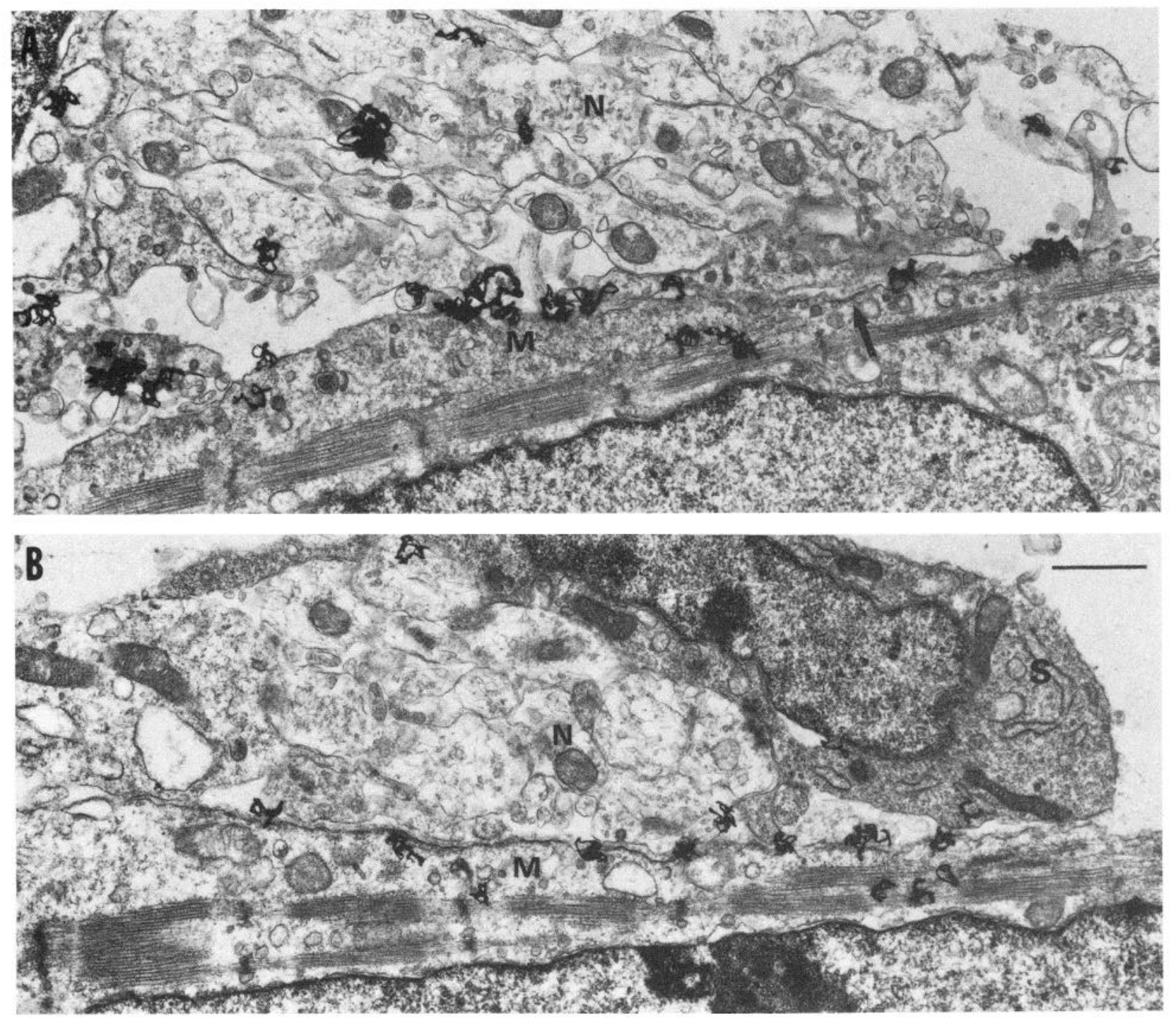

Figure 1. Examples of $\left[{ }^{125} \mathrm{I}\right] \alpha$-BTX autoradiograms of early neuromuscular contact areas in EDL muscles of 16 -day embryos $(129 / \mathrm{ReJ})$. In each, the nerve bundle $(N)$, consisting of several axons loosely wrapped by a Schwann cell(s), makes a close approach to the surface of a myotube $(M)$. In $A$, the nerve-muscle cleft is variable and the sarcolemma exhibits discontinuous bits of specialization (e.g., arrow) in the region of the contact. In contrast, in $B$, the cleft is more uniform and contains a discontinuous thin layer of basal lamina, and the sarcolemma displays a larger area with distinct thickening and a cytoplasmic substructure. Since these autoradiograms were exposed for the same length of time, their similar grain densities imply comparable $\left[{ }^{125} \mathrm{I}\right] \alpha$-BTX site densities, in spite of the differences in sarcolemmal differentiation. Bar $=1 \mu \mathrm{m}$. 
on a drop of lead citrate stain (Sato, 1968) for 1 to 1.5 min (being careful to avoid getting the lead stain on the back of the grid where it could contact the emulsion directly), washed carefully in many drops of distilled water, and dried.

EM autoradiograms were photographed on a Philips 201 or Philips 300 electron microscope at an initial magnification of $\times 7000$ to 10,000 and then printed at $\times 2.5$ to 3 additional magnification for analysis.

Absolute quantification of $\left[{ }^{125} \mathrm{I}\right] \alpha$-BTX binding sites/ $\mu \mathrm{m}^{2}$ (i.e., AChR site density) was calculated from autoradiograms as follows: Only regions of endplates in which the axonal and postjunctional membranes appeared crisp were analyzed, thus excluding regions where these membranes were sectioned tangentially. Developed grains were counted if they fell within $0.5 \mu \mathrm{m}$ on the axonal side or $1.0 \mu \mathrm{m}$ on the muscle side of the midline of the primary cleft. This ensured that we collected $>95 \%$ of the grains which would have arisen from a linear source along the crests of the junctional folds (Salpeter et al., 1969, 1977). Background values over an equal section area of muscle but at a distance from the neuromuscular junction were determined and subtracted from the grain count at the junction. (Background was, in fact, insignificant, accounting for $<2 \%$ of the junctional grains.) The values for AChR site density were calculated per $\mu \mathrm{m}^{2}$ of surface area either of specialized postjunctional membrane or of a surface parallel to the roof of the primary cleft $\left(1^{\circ} \mathrm{cleft}\right.$ midline). Since both surfaces are at right angles to the plane of the section, their areas were determined as previously described (Fertuck and Salpeter, 1976; Matthews-Bellinger and Salpeter, 1978) by measuring the lengths of either the membrane or the midline of the primary cleft (by the grid intersection method) and multiplying these lengths by the thickness of the sections (measured by interferometry) (Salpeter and Bachmann, 1972). The grains within the tabulated junctional area (after background subtraction) were expressed as grains per unit area of these surfaces. These values were used to calculate AChR site density as previously described (Fertuck and Salpeter, 1976; Matthews-Bellinger and Salpeter, 1978) from the specific activity of the $\left[{ }^{125} \mathrm{I}\right] \alpha$ BTX, the empirically determined autoradiographic sensitivity (see Fertuck and Salpeter, 1974b) and the exposure time. For the present experiments the sensitivity was on the average one grain per two radioactive decays.

\section{Results}

Morphological development of normal neuromuscular junctions. Our observations on the morphological differentiation of the mammalian neuromuscular junctions generally confirmed the descriptions given by other workers (Kelly and Zacks, 1969; Teräväinen, 1968; Korneliussen and Jansen, 1976; Rosenthal and Taraskevich, 1977; Nakajima et al., 1980; Bixby, 1981).

At 16 days in utero, the EDL muscle was mainly composed of myoblasts and multinucleated myotubes, with a few immature myofibers also forming. Intramuscular nerve branches consisted of multiple axons loosely and often incompletely wrapped into bundles by Schwann cells. Close approaches between these axon bundles and muscle cells occurred quite frequently. At many of these regions, the Schwann cell covering was partially absent on the side of the contact, allowing one or more small axon profiles to appose the muscle cell surface directly (Fig. 1). Frequently, we saw synaptic vesicles in the axon profiles and sparse bits of basal lamina in the irregular gap between axon and muscle. The muscle surface at these contacts often displayed intermittent membrane thickening, typically in small convex patches (Fig. 1 $A$ ). In some cases, these dense patches merged to form a nearly continuous sarcolemmal specialization (Fig. $1 B$ ), yet in no case did the regions of membrane thickening have as distinct a cytoplasmic filamentous substructure as is seen in the adult. Because of the difficulty of recognizing functional neuromuscular junctions in embryonic muscle, no quantitative description of these features was attempted.

During postnatal development, the major morphological features measured were the extent of junctional folds,

TABLE I

Changes in posljunclional morphology during postnatal development

Junctional morphology in EDL muscles was evaluated at several times during the first 2 postnatal weeks. The morphology of the postjunctional membrane was quantified by measuring the lengths of total pjm and of thickened pjm, and normalizing these to the length of the midline of the primary cleft. The resulting ratio of lengths "total pjm to $1^{\circ}$ cleft midline" is a measure of the extent of postjunctional membrane folding. The ratio "thickened pjm to $1^{\circ}$ cleft midline" is a measure of the relative amount of junctional surface area which is specialized thickened membrane. By dividing the two ratios, one can determine the proportion of the total pjm which is specialized at each age ( 52 to $58 \%$ between days 1 and 7 , and gradually falling thereafter to the adult value of $\sim 30 \%$ ). For most ages, $>800 \mu \mathrm{m}$ length of $1^{\circ} \mathrm{cleft}$ were analyzed (from 20 to 50 separate endplates); in these cases, the table gives the mean and standard error of the ratios obtained for the several muscle samples. For some ages, fewer total endplates were analyzed, and only the overall ratio is given without the error.

Total counts of coated vesicles within $1 \mu \mathrm{m}$ of the $1^{\circ}$ cleft were normalized by dividing by the volume of subjunctional tissue analyzed. Since most of the coated vesicles analyzed were actually lying very close to the pjm, the concentration of coated vesicles was considerably higher immediately under the junctional membrane and fell off sharply with distance from the pjm.

\begin{tabular}{|c|c|c|c|c|}
\hline \multirow[b]{2}{*}{$\begin{array}{c}\text { Strain } \\
\text { and Age }\end{array}$} & \multirow{2}{*}{$\begin{array}{c}\text { Total } \\
\text { Length of } \\
1^{\circ} \mathrm{Cleft} \\
\text { Analyzed } \\
(\mu \mathrm{m})\end{array}$} & \multicolumn{2}{|c|}{ Ratio of Lengths } & \multirow{2}{*}{$\begin{array}{l}\text { No. of Coated } \\
\text { Vesicles/ } / \mu m^{3} \\
\text { under the } \\
\text { Junction }^{a}\end{array}$} \\
\hline & & $\begin{array}{c}\text { Total pjm to } 1^{\circ} \\
\text { Cleft Midline }\end{array}$ & $\begin{array}{c}\text { Thickened pjm } \\
\text { to } 1^{\circ} \text { Cleft } \\
\text { Midline }\end{array}$ & \\
\hline \multicolumn{5}{|l|}{ 129/ReJ } \\
\hline 1 day $(4)^{b}$ & 826.2 & $1.14 \pm 0.006$ & $0.58 \pm 0.05$ & $4.2 \pm 0.29^{c}$ \\
\hline 3 days $(4)$ & 1119.3 & $1.24 \pm 0.04$ & $0.69 \pm 0.03$ & $3.4 \pm 0.23$ \\
\hline 5 days $(3)$ & 1080.6 & $1.23 \pm 0.05$ & $0.67 \pm 0.02$ & $1.4 \pm 0.07^{c}$ \\
\hline 7 days $(2)$ & 134.1 & 1.94 & 0.86 & 1.9 \\
\hline 14 days (4) & 1097.0 & $2.03 \pm 0.07$ & $0.73 \pm 0.06$ & $1.1 \pm 0.17$ \\
\hline 15 days (3) & 148.1 & 2.25 & 0.87 & 1.1 \\
\hline Adult (5) & 967.9 & $4.40 \pm 0.33$ & $1.30 \pm 0.05$ & $0.9 \pm 0.05$ \\
\hline \multicolumn{5}{|l|}{ Albino } \\
\hline 2 days (2) & 358.0 & & 0.63 & 2.0 \\
\hline Adult (2) & 120.1 & 4.82 & 1.24 & \\
\hline
\end{tabular}

${ }^{a}$ Cubic micrometers were determined by multiplying the surface area of autoradiograms tabulated by the thickness of the section.

${ }^{b}$ Numbers in parentheses indicate the number of muscles sampled.

${ }^{\circ}$ Significantly different from each other $(p<0.001)$ by two-tailed $t$ test. 

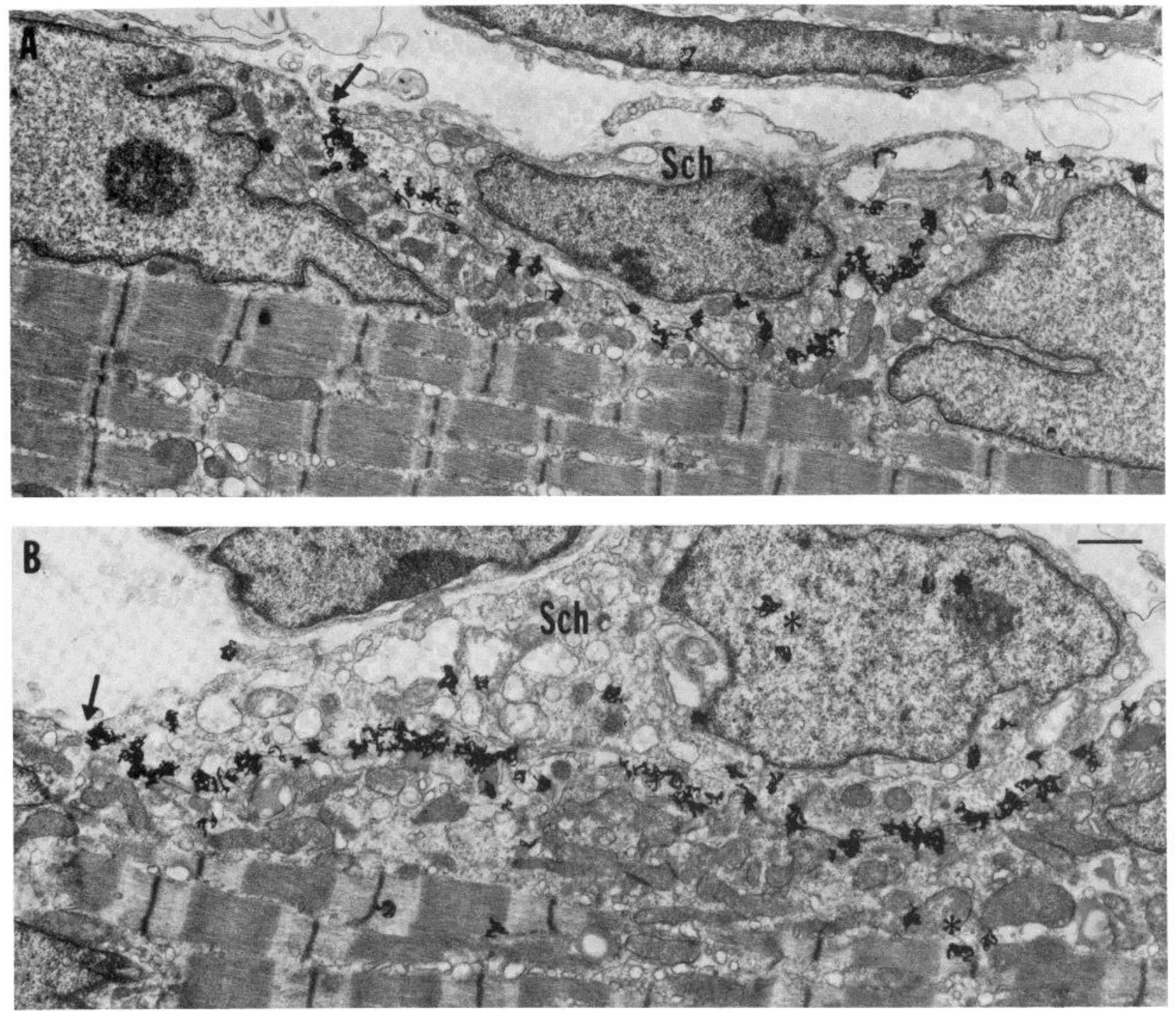

Figure 2. Low magnification overviews of high exposure autoradiograms of two neuromuscular junctions from 1-day-old neonates (129/ReJ). Numerous small axon terminals are embedded in an overlying Schwann cell (Sch). In $A$, the entire prejunctional structure lies indented into the muscle surface. All muscle surface contacted by either axon terminal or Schwann cell was considered junctional. The edges of this "junctional complex" are typically very distinct by birth (arrows in $A$ and $B$ ), and high density grain accumulations rarely extend beyond this boundary. Asterisks in $B$ indicate several nonjunctional grains over muscle or Schwann cytoplasm, reflecting the elevated density of nonjunctional sites in neonatal muscle. $B a r=1 \mu \mathrm{m}$.

the amount of specialized dense postjunctional membrane, the proportion of primary cleft covered by Schwann cells or axon terminals, and the frequency of coated vesicles in the subjunctional sarcoplasm (Table I). Measurement of the dense postjunctional membrane was particularly difficult since the exact nature of the morphological specialization changed with development. In general, dense membrane appeared distinctly different from the typical plasma membrane: it was more electron dense, with a smooth straight or convex contour and usually (although not always) with an underlying cytoplasmic fuzz.

By 1 day postpartum, the junctional morphology was quite clearly defined, although considerable fine structural variation was still present. Generally, several small axon profiles covered by an overlying Schwann cell clustered together in contact with the muscle cell surface
(Fig. 2). The entire region where axons and Schwann cells are closely apposed to the muscle surface is included in what we term the "junctional complex." The $1^{\circ}$ cleft defined by this junctional complex was usually of uniform width and contained a distinct basal lamina. The postjunctional membrane was intermittently thickened and had occasional indentations, but junctional folds were rarely seen (Fig. 3). Coated vesicles were a prominent feature of the sarcoplasm near the pjm (Fig. 3) and were sometimes seen to be open to the $1^{\circ}$ cleft or to smooth membranous cisternae just under the pjm. As indicated in Table I, the concentration of subjunctional coated vesicles within $1.0 \mu \mathrm{m}$ of the $1^{\circ}$ cleft (1 day postpartum) was $4.2 \pm 0.5 / \mu \mathrm{m}^{3}$. Approximately $: 30 \%$ of these lay within $0.5 \mu \mathrm{m}$ of the pjm. We also determined that coated vesicles were 6 to 8 times more frequent near the pjm than near extrajunctional sarcolemma. Thus, there are 
steep gradients in concentration of coated vesicles with distance from the junction. Coated vesicles found deeper than $0.5 \mu \mathrm{m}$ in the subjunctional sarcoplasm were often related to Golgi lamellae. In addition, small clear multivesicular bodies were frequently present, usually near a Golgi apparatus.

Table I shows that the postjunctional morphology was nearly constant during the first 5 postnatal days, except for a dramatic decrease in the concentration of subjunctional coated vesicles. Between 1 and 5 days, a large proportion $(54 \pm 5 \%)$ of the $1^{\circ}$ cleft area within the junctional complex was apposed by Schwann cell processes rather than axon terminals (Fig. 3). An analysis was done to compare the amounts of postjunctional membrane specialization in these regions. Overall, there was a significantly higher percentage of thickened membrane that appeared under axon terminals $(76 \pm 3)$ than under Schwann cell $(53 \% \pm 6)$. It was quite striking, however, that in regions covered by Schwann cell processes, more than half of the muscle membrane was noticeably dense or thickened. In contrast, regions of plasma membrane outside the junctional complex almost never showed similar specialization.

Between 5 and 15 days postpartum there was an overall increase in junctional fold differentiation which seemed to occur in a nonsynchronous manner even for nearby junctions within a single muscle. During this period, the individual axon terminals became separated both by muscle ridges and by Schwann cell extensions and the number of terminal profiles per endplate declined. This is consistent with the timing of the elimination of redundant innervation in other species (Brown et al., 1976; Rosenthal and Taraskevich, 1977; Korneliussen and Jansen, 1976; Bixby and van Essen, 1979). Schwann cells were sometimes unusually electron dense in this phase, with condensed nuclear chromatin, and more prominent Golgi apparati, rough endoplasmic reticulum, and lysosome-like dense bodies. By 2 weeks the surviving terminals were enlarged and covered most of the $1^{\circ}$ cleft of the junctional complex (Fig. 4). Schwann contact with the $1^{\circ}$ cleft was generally restricted to the edges of the junction, as in the adult.

Postjunctional maturation continued after 2 weeks. The major change was an increase in the number and average depth of the junctional folds, resulting in a more than 2-fold increase in the amount of total pjm and a 1.6fold increase in the amount of thickened pjm per unit area of primary cleft (Fig. 5, Table I). The decreased distance between folds was associated with a marked enhancement of the curvature of the membrane at the crests of the folds.

Since all the above observations were obtained using mice of strain 129/ReJ, we examined the junctional morphology in EDL muscles of the more commonly studied albino mice for comparison. Adult junctional morphology is essentially the same in these two strains (Table I and previous observations). Similarly, postjunctional morphology was indistinguishable for neonates of the two strains (although slightly fewer coated vesicles were seen in the small sample of 2-day albino junctions analyzed) (Table I, Fig. 3). The exact time course of the observed changes may differ somewhat for different strains or species. For instance, junctional maturation, and especially the development of junctional folds, may be slightly slower in $129 / \mathrm{ReJ}$ mice than in rats (see Rosenthal and Taraskevich, 1977; Teräväinen, 1968; Kelly and Zachs, 1969). However, there is no reason to believe that the sequence of changes is different.

$\alpha-B T X$ binding at mature neuromuscular junctions. Figure 5 shows an autoradiogram of a junction from adult EDL muscle labeled with $\left[{ }^{125} \mathrm{I}\right] \alpha$-BTX after prefixation. The $\alpha$-BTX binding is primarily restricted to the crests of the junctional folds, in the region of thickened membrane, as previously described (Fertuck and Salpeter, 1974a, 1976; Porter and Barnard, 1975; Matthews-Bellinger and Salpeter, 1978; Land et al., 1980). This localization was not affected by the prefixation used in the present protocol.

Prefixation also did not affect the absolute number of $\left[{ }^{125} \mathrm{I}\right] \alpha$-BTX binding sites (Table II). However, we consistently observed a difference in the $\alpha$-BTX binding site density between strains of mice (Table II). Whereas the $\left[{ }^{125} \mathrm{I}\right] \alpha-\mathrm{BTX}$ site density at EDL and sternomastoid endplates from Swiss albino mice matches the junctional site density seen in other muscles of Swiss albino mice (e.g., diaphragm, soleus; results unpublished), the $\left[{ }^{125} \mathrm{I}\right] \alpha$-BTX site densities obtained for EDL and soleus muscles of mice of the strain 129/ReJ matched each other but are significantly lower ( 230 to $50 \%)$ than that seen in albino animals. These lower values in the inbred strain are not artifacts of prefixation (Table II). Nor are they a failure to saturate the specific junctional sites, since control studies in both adults and 2-day neonates (see "Materials and Methods") indicated that $>95 \%$ of the junctional sites were saturated by our labeling procedure. It also is not due to a miscalibration of the specific activity of the batches of $\left.{ }^{125} \mathrm{I}\right] \alpha$-BTX used in these studies, since disparate junctional site densities were found for albino and $129 /$ ReJ mice using the same batch of $\left[{ }^{125} \mathrm{I}\right] \alpha$-BTX. These observations indicate that the unexpectedly low AChR densities reported here for both developing and adult junctions are characteristic of the inbred strain of mice used.

$\alpha-B T X$ binding site densities at developing junctions. Table III shows that the number of junctional binding sites per unit surface area of junction (sites $/ \mu \mathrm{m}^{2} 1^{\circ}$ cleft midline) increases 2 - to 3-fold during postnatal development while the site density per unit surface of specialized thickened pjm is essentially constant. This correlation of sites and thickened pjm is consistent with the hypothesis that at all postnatal ages, the AChR is primarily localized on regions of morphologically specialized postsynaptic membrane.

The postjunctional membrane of neonatal junctions constitutes a mosaic of small regions of dense pjm with considerable cytoplasmic filaments interspersed with morphologically less specialized pjm (Fig. 3). Since limits in the autoradiographic resolution preclude a separate assessment of the radiation from each of these regions, we could not test for the presence of some receptors on the nonspecialized membrane. Such membrane may resemble the nonspecialized membrane regions adjacent to the developing junction, where a perijunctional AChR gradient is a prominent feature (Bevan and Steinbach, 1977; Diamond and Miledi, 1962).

However, two additional analyses were done which 

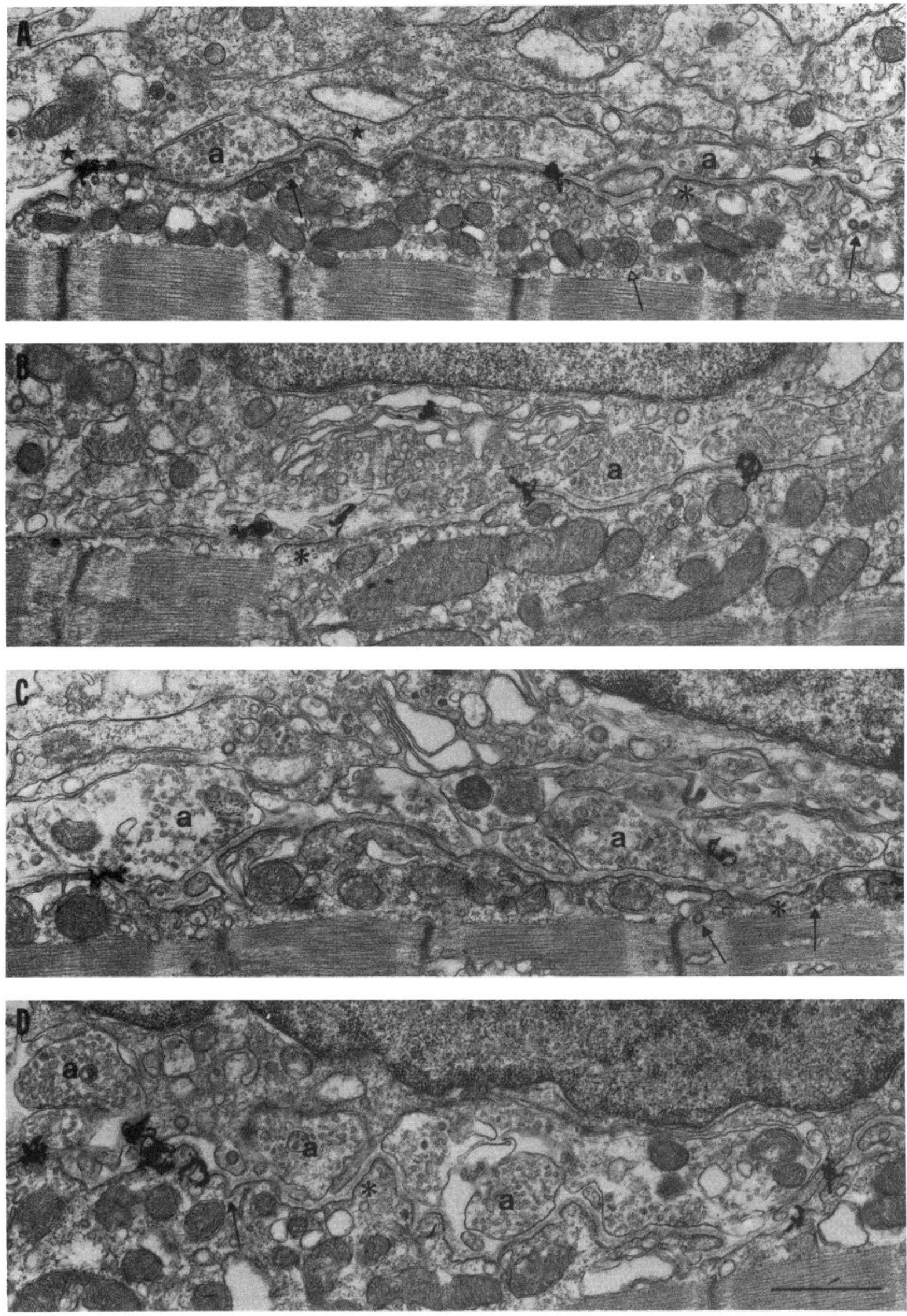

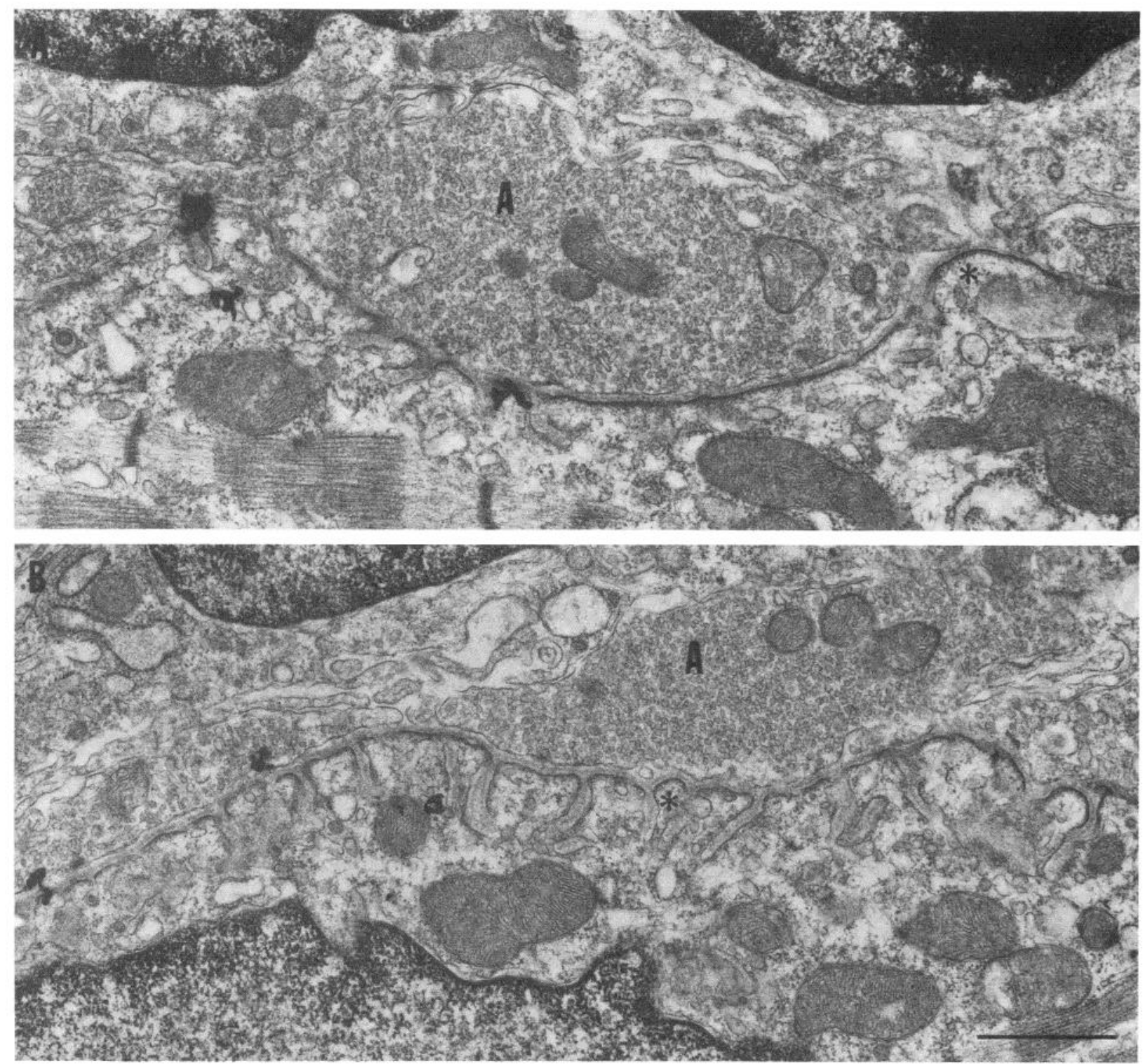

Figure 4. Autoradiograms of neuromuscular junctions from 2-week-old mice (129/ReJ). The number of terminals per unit area of junction has decreased, and the remaining terminals have enlarged to cover most of the primary cleft. As seen in $A$, the nucleus of the overlying Schwann cell is often electron dense. Regions of postjunctional membrane which face the primary cleft are distinctly and uniformly thickened with an overlying basal lamina and a cytoplasmic undercoat comparable to that seen in adult junctions (asterisks). However, the extent of folding of the pjm varies greatly (compare $A$ and $B$ ), and even when folds are well developed, they are more widely spaced and shallower than in mature junctions $(B)$. Autoradiographic grains are largely restricted to a band overlying the primary cleft. $B a r=1 \mu \mathrm{m}$.

confirm that the bulk of $\left[{ }^{125} \mathrm{I}\right] \alpha$-BTX binding sites is most likely associated with regions of thickened membrane. In the first case, on 5-day-old junctions, the postjunctional membrane under Schwann cell was analyzed separately from that under axon terminals. In the second analysis, on junctions from 14-day-old muscles, endplate micrographs were subdivided into two groups based on the extent of folding of the pjm. Although for each of the

Figure 3. Low exposure $\left[{ }^{125} \mathrm{I}\right] \alpha$-BTX autoradiograms of neuromuscular junctions in neonatal mouse EDL muscles. $A$, 1-day-old $129 / \mathrm{ReJ}$ mouse; $B, 2$-day-old albino mouse; $C$ and $D, 3$-day-old $129 / \mathrm{ReJ}$ mouse. Presynaptically, the primary cleft is apposed by multiple small axon terminals, only some of which are indicated $(a)$, as well as by portions of Schwann cell cytoplasm (stars in $A$ ). Most of the postjunctional membrane which faces the primary cleft is thickened (e.g., asterisks in $A, B$, and $D$ ), although the membrane density and the amount of cytoplasmic filamentous coat varies from region to region. Junctional folds are rare and when they occur are shallow and unbranched. Subjunctional sarcoplasm is rich in coated vesicles and coated pits (solid arrows), and multivesicular bodies are frequently seen (open arrow in $A$ ). In $D$, ridges of sarcoplasm and extensions of Schwann cytoplasm are beginning to segregate individual axon terminals, a process which becomes quite prominent at most junctions around the end of the first week after birth. Bar $=1 \mu \mathrm{m}$. 
above analyses, the subgroups differed significantly in their ratios of thickened pjm to primary cleft line (in the day 5 group they were $0.76 \pm 0.02$ versus $0.53 \pm 0.04$; and in the day 14 group they were $0.84 \pm 0.03$ versus $0.53 \pm$ 0.01 ), the $\alpha$-BTX site density $/ \mu \mathrm{m}^{2}$ of thickened pjm remained constant (in the day 5 group, they were $7900 \pm$ 636 versus $7800 \pm 577$; and in the day 14 group they were $8500 \pm 751$ versus $9700 \pm 1270$ ).

In contrast to the junctions during postnatal development, a preliminary analysis on prenatal junctions showed no clear association between $\alpha$-BTX binding and specialized membrane. In muscles sampled at embryonic day 16 , we saw sarcolemmal accumulations of grains which generally occurred quite near the path of a nerve or at an apparent nerve-muscle contact (Fig. 1), but often extended well beyond the region of actual contact. Neuromuscular contacts which displayed membrane thickening generally also had grain accumulations. However, similar grain accumulations occurred over contact regions which had little if any obvious membrane thickening. The average $\left[{ }^{125} \mathrm{I}\right] \alpha$-BTX site density was $\sim 2200 /$ $\mu \mathrm{m}^{2}$ of membrane contacted by nerve. Contact areas could be classified as having either conspicuous or sparse sarcolemmal thickening. If contact regions were selected for analysis only if they had extensive patches of specialized dense membrane, and the site density was then calculated as if the sites were restricted to these patches, the average BTX site density was 2800 sites $/ \mu \mathrm{m}^{2}$. Thus an association of grain clusters with distinct membrane thickening was not as obvious as in the postnatal junctions. Furthermore, even when associated with dense membrane, these early clusters had considerably lower $\mathrm{AChR}$ site densities than seen later.
The embryonic muscle, like the adult muscles, was prefixed prior to labeling with $\left[{ }^{125} \mathrm{I}\right] \alpha$-BTX. We have shown that prefixation does not alter the BTX binding in postnatal muscles (Table II). However, it is conceivable that embryonic AChRs have decreased capacity to bind $\alpha$-BTX under our fixation conditions. This is not likely since embryonic receptors on rat primary muscle cells in vitro are unaffected by relatively gentle fixation

\section{TABLE II}

Junctional $\left[{ }^{125} I\right] \alpha-B T X$ binding site density in muscles of adult mice Comparison of acetylcholine receptor concentrations, as determined by $\left[{ }^{125} \mathrm{I}\right] \alpha$-BTX binding site densities at saturation (see "Materials and Methods") for neuromuscular junctions of adult mouse muscles labeled either before or after primary fixation. $\left[{ }^{125} \mathrm{I}\right] \alpha$-BTX site densities, expressed per $\mu \mathrm{m}^{2}$ postjunctional thickened membrane, are given for sternomastoid (SM) and extensor digitorum (EDL) muscles of albino animals and for soleus (SOL) and EDL muscles of 129/ReJ animals. Each value represents the mean and standard error for several (three to seven) muscle regions sampled from one or more animals (tabulating $>100$ grains/animal). Numbers in parentheses indicate the number of animals examined. No consistent differences were found between maximal binding site densities of muscles labeled before or after fixation. Within a mouse strain, different muscles exhibited comparable binding site densities. However, junctional site densities were consistently lower in muscles of $129 / \mathrm{ReJ}$ mice as compared with albino mice.

\begin{tabular}{llcc}
\hline \multirow{2}{*}{ Strain } & Muscle & \multicolumn{2}{c}{$\left[{ }^{125} \mathrm{I}\right] \alpha$-BTX Site Density $/ \mu \mathrm{m}^{2}$ Thickened pjm } \\
\cline { 3 - 4 } & & Labeled before Fixation & Labeled after Fixation \\
\hline Albino & SM & $18,700 \pm 1,041(3)^{\alpha}$ & $17,150 \pm 1,699(2)$ \\
Albino & EDL & $20,600 \pm 2,200(1)^{a}$ & $21,800 \pm 1,443(2)$ \\
129/ReJ & EDL & $8,200 \pm 247(1)$ & $12,100 \pm 2,021(4)$ \\
$129 / \mathrm{ReJ}$ & SOL & $6,900 \pm 1,202(1)$ & \\
\hline
\end{tabular}

${ }^{a}$ Data from Dr. Ralph Loring (personal communication).

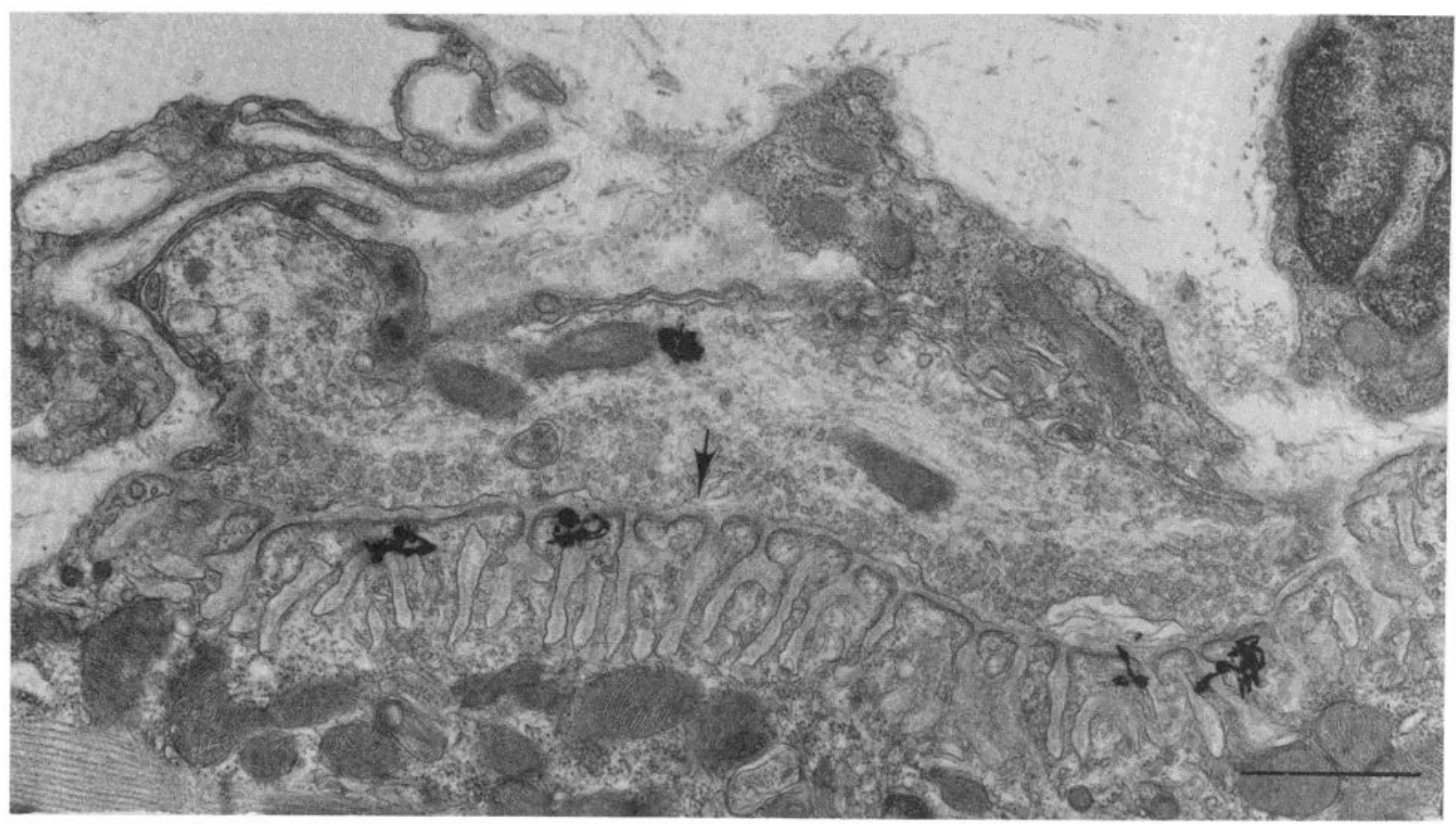

Figure 5. Autoradiogram of typical neuromuscular junction in EDL muscle of adult 129/ReJ mouse showing mature morphology of the pjm. Junctional folds are deep and regularly spaced every 0.2 to $0.4 \mu \mathrm{m}$, giving the thickened membrane at the crests of the folds (arrow) a scalloped appearance. Autoradiographic grains lie within a band around this region of thickened membrane. This level of exposure is deemed ideal for grain tabulation. Bar $=1 \mu \mathrm{m}$. 
TABLE III

Junctional $\left.{ }^{125} I\right] \alpha-B T X$ binding site density during postnatal development

Junctional acetylcholine receptor site densities ( $\left[{ }^{125} \mathrm{I}\right] \alpha-\mathrm{BTX}$ binding site densities) were determined for developing endplates in EDL muscles at 1, 3, 5, and 14 days after birth and for adults ( $>3$ months). All animals were of strain 129/ReJ; the number of animals sampled at each age is indicated in parentheses. All of the immature muscles and three of the five adult muscles were labeled after prefixation. Junctional site densities (mean and standard error) are expressed both as sites $/ \mu \mathrm{m}^{2}$ of junctional surface (sites $/ \mu \mathrm{m}^{2} \mathrm{I}^{\circ}$ cleft midline) and as sites $/ \mu \mathrm{m}^{2}$ of specialized thickened membrane. Since, as indicated, at least 200 autoradiographic grains were collected for each analysis, the overall autoradiographic sampling error $\left(\frac{100}{\sqrt{\mathrm{N}}}\right)$ at each stage was always $<$ $10 \%$.

\begin{tabular}{lccc}
\hline \multirow{2}{*}{ Age } & No. of Grains & \multicolumn{2}{c}{${ }^{\left.{ }^{125} \mathrm{~T}\right] \alpha \text {-BTX Site Density }}$} \\
\cline { 3 - 4 } & Counted & $\begin{array}{c}\text { per } \mu \mathrm{m}^{2} \\
1^{\circ} \text { Cleft Midline }\end{array}$ & $\begin{array}{c}\text { per } \mu \mathrm{m}^{2} \\
\text { Thickened pjm }\end{array}$ \\
\hline One day (4) & 224 & $4,850 \pm 520$ & $8,200 \pm 606$ \\
Three days (4) & 500 & $6,300 \pm 779$ & $9,050 \pm 866$ \\
Five days (3) & 266 & $5,250 \pm 530$ & $7,900 \pm 672$ \\
Fourteen days (4) & 335 & $6,400 \pm 491$ & $8,800 \pm 693$ \\
Adult (5) & 845 & $14,050 \pm 2,650$ & $10,950 \pm 2,225$ \\
\hline
\end{tabular}

and extensive washing protocol similar to the one used here (unpublished data from our laboratory; see also Sytkowski et al., 1973; Fambrough and Devreotes, 1978).

Cytoplasmic label. Muscles from prenatal and neonatal mice (both albino and 129/ReJ) showed higher labeling of the cytoplasm of various cell types (Figs. 1 and 2) than was seen in adult muscles labeled under identical conditions (with or without prefixation). The nonjunctional label was generally heavier over myogenic cells, especially near regions of nerve-muscle contact, and was also notable over immature Schwann cytoplasm. At least some of the sarcoplasmic sites in neonatal muscle are specific, since, in one experiment on 2-day-old albino animals, the label over muscle cytoplasm due to binding of $\left[{ }^{125} \mathrm{I}\right] \alpha$-BTX was reduced by approximately $50 \%$ by pretreatment of the muscle with unlabeled toxin (under conditions that saturated $>98 \%$ of the junctional sites). Note that this elevated non-plasma membrane label was seen, even though we did not use any treatment intended to expose internal sites (e.g., saponin pretreatment; Fambrough and Devreotes, 1978; Atsumi, 1981), and was also observed in one experiment on neonatal muscle labeled prior to fixation. No specific localization relative to any cellular organelle was apparent, although no detailed quantification was performed. A survey of muscles at different ages by light microscope autoradiography indicated that the sarcoplasmic label declined with age, approaching the low levels normally seen in adult muscles by approximately 2 weeks after birth. Similar cytoplasmic $\alpha$-BTX binding has been seen in muscle cells grown in vitro (Land et al., 1977; Podleski et al., 1979; Salpeter et al., 1982) and after denervation (Loring and Salpeter, 1978).

\section{Discussion}

In the present study we examined the relationship between AChR distribution and various morphological features of the pjm at developing neuromuscular junc- tions. Our data can be discussed in terms of four stages for the maturation of the junctional fine structure: embryonic day 16 to birth; the first postnatal week; the second postnatal week; and from 2 weeks to adult.

The first period spans from the onset of the differentiation of the neuromuscular junction in the embryo up to approximately birth. Neuromuscular transmission in rodent muscles begins at or before day 15 in utero (Diamond and Miledi, 1962; Dennis et al., 1981), at a time when AChR is distributed uniformly over the entire surface of the myotube (Bevan and Steinbach, 1977; Braithwaite and Harris, 1979). AChR accumulates in the region of nerve-muscle contact about 1 to 2 days later (Bennett and Pettigrew, 1974; Bevan and Steinbach, 1977; Braithwaite and Harris, 1979).

Patches of junctional membrane specializations characterized by increased electron density and membrane thickening are first seen at approximately the same time as is receptor accumulation (Teräväinen, 1968; Kelly and Zachs, 1969), suggesting an association between these processes. However, in our analysis of embryonic mouse junctions, we found an equivalent site density of AChR of $\sim 2000$ to $3000 \mathrm{sites} / \mu \mathrm{m}^{2}$ of surface area whether or not extensive dense membrane specializations were obvious. These data suggest that initial synaptic receptor accumulation and the differentiation of extensive membrane density are not coincident. Such a conclusion is tentative because the early membrane specializations may be less easy to visualize than those seen postnatally. Until the critical components of the dense membrane are determined and those associated with $\mathrm{AChR}$ clustering are identified, the functional relationship between "dense membrane" and AChR clustering cannot be assessed. The results also show that the AChR site density within clusters which are seen at the 16-day embryonic nervemuscle contact region, although considerably higher than that at extrajunctional regions, does not have adult values. There must, therefore, be a time-dependent increase in AChR site density within these clusters in contact with the nerve. The distribution of AChR at very early subneural regions in embryonic mouse muscle resembles that in receptor aggregates on uninnervated rat myotubes in vitro in two respects: the concentration of $\mathrm{AChR}$ within the aggregate is $\sim 3000 / \mu \mathrm{m}^{2}$ of sarcolemma (Land et al., 1977; Salpeter et al., 1982), and, although dense membrane specialization occurs preferentially at receptor aggregates, they are not as distinct a correlate of the entire region of elevated receptor concentration as at later times (Hourani et al., 1974; Vogel and Daniels, 1976; Salpeter et al., 1982). Furthermore, addition of nerve factors to these cultures induces an elevation of the AChR site density within the myotube clusters which occurs during a period of several days (Salpeter et al., 1982). Braithwaite and Harris (1979) have shown that, even if the nerve is not allowed to grow to the embryonic muscle, receptors will accumulate in the region of the endplate band. It would be interesting to see what the AChR site density in these noninnervated clusters is and whether that site density ever increases in the absence of nerve.

In contrast to the prenatal data, the AChR accumulations were consistently associated with conspicuous 
dense membrane specializations for all postnatal ages examined (although the specialized regions of membrane were often less distinct than in the adult), and the AChR site density on the dense membrane was constant postnatally at $\sim 9000 / \mu \mathrm{m}^{2}$ of thickened membrane. Thus, even though early subneural AChR clusters may not initially be associated with distinct regions of dense membrane, they become so prior to birth. The 3-fold increase in local receptor site density between embryonic day 16 and birth may be related to this coupling with dense membrane.

These observations on embryonic mouse subneural AChR aggregates differ somewhat from those reported earlier for embryonic chick junctions. Using horseradish peroxidase (HRP)-BTX to examine the distribution of AChR at embryonic chick neuromuscular junctions, Jacob and Lentz (1979) concluded that the subneural HRP reaction product was always associated with small patches of morphologically distinct dense muscle membrane, even at the earliest age examined (day 10 in ovo). Burden has also shown by quantitative light microscope autoradiography that the junctional density of AChRs in chick has achieved the adult level of $\geq 10,000$ AChRs/ $\mu \mathrm{m}^{2}$ by day 14 in ovo or earlier (see Fig. 3 of that paper). However, in chicks, the first neuromuscular contact occurs around embryonic day 4 to 6 (Landmesser and Morris, 1975; Atsumi, 1977). Thus, the initial stage of receptor aggregation has not been examined in the chick.

The early subneural receptor aggregate undergoes other related maturational changes between embryonic day 16 and birth. The metabolic turnover rate decreases to the level seen at mature junctions (Berg and Hall, 1975; Steinbach et al., 1979; Michler and Sakmann, 1980; Reiness and Weinberg, 1981). Concurrently, the subneural receptor aggregate becomes resistant to various treatments which have been shown to disperse immature receptor aggregates (Bloch and Steinbach, 1981). In addition, the basal lamina, which at embryonic day 16 is often sparse and discontinuous (as it is in the noninnervated myotube, e.g., Salpeter et al., 1982) becomes a continuous sheet overlying the primary cleft by birth. It seems probable that the linking of AChR to submembrane or extracellular specializations provides the macromolecular machinery responsible for organizing and stabilizing the AChR within the postjunctional membrane. Recent observations on Torpedo electric organ synaptic membranes support the hypothesis that the submembrane cytoplasmic density is involved in anchoring the AChR in these membranes (Cartaud et al., 1981). Alternatively, there is evidence that the basal lamina may play a major role in organizing or immobilizing the AChR (Burden et al., 1979; Vogel et al., 1981; Salpeter et al., 1982).

The second stage, from birth to around 6 days postpartum, can be described as a quiescent period. There is little or no change in the amount of receptor per unit area of junction or the extent of postjunctional membrane specializations (Table I). Numerous physiological studies have shown that there are no major changes in the character of neuromuscular transmission during this period. Junctions remains multiply innervated, and miniature endplate potential (mepp) frequency and mean endplate potential (epp) quantal content continue to be low (Diamond and Miledi, 1962; Redfern, 1970; Bennett and Pettigrew, 1974; Dennis et al., 1981).

One significant morphological change during the first week was a dramatic decrease in the number of coated vesicles in the subjunctional sarcoplasm. The presence of coated vesicles in the postsynaptic cytoplasm at a variety of types of developing synapses has stimulated considerable speculation concerning their possible role in the production of synaptic specializations or the transport of synaptic macromolecules (Altman, 1971; Rees et al., 1976; Rees, 1978; Bursztajn and Fischbach, 1980; Fambrough and Devreotes, 1978; Atsumi, 1981). One hypothesis is that the coated vesicles transport "preformed" units of receptor-rich membrane for local insertion into the newly forming postsynaptic membrane. The data presented here suggest that this may not be a major function of the bulk of coated vesicles at neonatal junctions. The observed number of subsynaptic coated vesicles was high at birth, declined rapidly from day 1 to day 5 after birth, and remained essentially constant thereafter (Table I). Yet there is no evidence of any massive insertion of AChR occurring just after birth when coated vesicles were most common: there is virtually no change in either the number of AChRs $/ \mu \mathrm{m}^{2} 1^{\circ}$ cleft midline (reported here) or the total amount of junctional surface area per endplate (Bevan and Steinbach, 1977) during that period, and the turnover rate has already become slow prior to birth (Berg and Hall, 1975; Steinbach et al., 1979; Michler and Sakmann, 1980; Steinbach, 1981). Conversely, there is no increase in the number of coated vesicles during the period from 1 week to young adulthood when the endplate is undergoing rapid growth of receptor-rich membrane, junctional fold membrane, and total surface area. Thus, there does not seem to be a simple correlation between the presence of the coated vesicles and the insertion of junctional AChR or the expansion of postjunctional surface area. If coated vesicles are involved in $\mathrm{AChR}$ insertion, then this function must reside in a subpopulation of such vesicles which remains to be identified.

During the second stage, Schwann cell processes were regularly seen over regions of dense membrane, with associated $\alpha$-BTX binding sites, and over incipient junctional folds (see also Rosenthal and Taraskevich, 1977; Jacob and Lentz, 1979), although the amount of such specializations was somewhat less under Schwann extensions than under axonal profiles. These specializations were not seen beyond the edge of the "junctional complex," where neither axon terminal nor Schwann cell overlay the muscle surface. AChR aggregation at neuromuscular contacts is presently believed to be induced specifically in response to the ingrowing motor nerve (Frank and Fischbach, 1977, 1979; Bevan and Steinbach, 1977; Anderson and Cohen, 1977; Anderson et al., 1977; Weldon and Cohen, 1979), involving, in part, a redistribution of pre-existing receptors to regions of nerve muscle contact (Anderson and Cohen, 1977; Matthews-Bellinger and Fischbach, in preparation). The broader distribution of specializations within the $1^{\circ} \mathrm{cleft}$ to include regions under Schwann cells could arise if the axon terminals move within the $1^{\circ}$ cleft to directly contact, at different 
times, the entire junctional sarcolemma. The induction of specializations might then be mediated by a specific contact effect between axon and muscle. Alternatively, the nerve terminal may produce the sarcolemmal differentiation by releasing an "inducer" substance (Podleski et al., 1978; Christian et al., 1978; Jessell et al., 1979; Bauer et al., 1981; Salpeter et al., 1982) which diffuses throughout the $1^{\circ}$ cleft to interact with an area larger than that directly contacted by the terminal. The Schwann might also act to restrict or concentrate this substance within the junctional borders of the $1^{\circ}$ cleft and/or to modulate its effect.

The third stage, from day 7 through the second postnatal week, is a period of rapid developmental changes at the junction. The surface area of endplate increases (Bevan and Steinbach, 1977) and deep junctional folds begin to form, as seen in the increasing ratio of total pjm to surface area (Table I). Since the ratio of specialized dense membrane to surface area increases less rapidly, the percentage of the total pjm occupied by dense pjm decreases from $54 \%$ to $38 \%$. The early junctional folds differ from adult folds in that they are more widely spaced, slightly shallower, and less branched. As a result of the wider spacing, the dense membrane at the crests of the folds has less curvature or "scalloping" than in the adult.

Physiological evidence indicates that in rodent muscles the elimination of multiple innervation occurs largely during this stage and is nearly complete by 14 to 15 days after birth (Redfern, 1970; Bennett and Pettigrew, 1974; Brown et al., 1976; Rosenthal and Taraskevich, 1977; O'Brien et al., 1978; Dennis et al., 1981). Consistent with these physiological findings and with earlier morphological findings (Korneliussen and Jansen, 1976), we observed fewer terminals per endplate profile during this period than in neonates. Changes in the endplate physiology and pharmacology are also occurring during this third period. Most relevant to our study are: (1) increases in both epp quantal content and mepp frequency (Diamond and Miledi, 1962), which may reflect the increase in presynaptic axonal surface area (Kelly, 1978); and (2) a change in the receptor gating rate (Sakmann and Brenner, 1978; Michler and Sakmann, 1980; Fischbach and Schuetze, 1980) for which no obvious morphological correlate can be cited. 'The specialized dense membrane, in which the receptor primarily resides, seems to change very little during this period either in terms of absolute amount or in morphology.

The fourth and final period of junctional maturation, extending from 2 weeks to the adult, is characterized by a continued parallel increase (Table I) in both dense specialized membrane (1.6-fold) and total junctional fold membrane $(\sim 2$-fold $)$. The interfold distance decreases and the receptive membrane at the crest of the folds acquires the characteristic scalloping seen in the adult (i.e., it curves and extends about $2000 \AA$ down from the top of the folds). Others have reported a continuous enlargement of the junction (Steinbach, 1981) and a parallel increase in epp quantal content (Kelly, 1978) during this period, which roughly keep pace with the increase in the size of the muscle fiber. In addition, beginning around the second postnatal week, there are changes in the gross structure and complexity of the endplate which distinguish fast- and slow-type fibers (Tweedle and Stephens, 1981). Therefore, the period from 2 weeks to adult may be particularly appropriate for studying the physiological consequence of elaboration of junctional folds and of endplate resculpturing.

In conclusion, we found that at 16-day embryonic neuromuscular contacts, the concentration of accumulated $\mathrm{AChRs}$ is $\sim 3000$ sites $/ \mu \mathrm{m}^{2}$. These early clusters overlap but do not necessarily coincide with regions of distinctly thickened postjunctional membrane. However, by birth, postjunctional AChR clusters have adult receptor densities and are always associated with regions of dense specialized membrane. Thereafter, an increase in the amount of AChR per endplate is coupled to an increase in specialized dense membrane, which is, in turn, associated with the development of junctional folds.

\section{References}

Altman, J. (1971) Coated vesicles and synaptogenesis. A developmental study in the cerebellar cortex of the rat. Brain Res. 30: 311-322.

Anderson, M. J., and M. W. Cohen (1977) Nerve-induced and spontaneous redistribution of acetylcholine receptors on cultured muscle cells. J. Physiol (Lond.) 268: 757-773.

Anderson, M. J., M. W. Cohen, and E. Zorychta (1977) Effects of innervation on the distribution of acetylcholine receptors on cultured muscle cells. J. Physiol. (Lond.) 268: 731-756.

Atsumi, S. (1977) Development of neuromuscular junctions of fast and slow muscles in the chick embryo: A light and electron microscopic study. J. Neurocytol. 6: 691-709.

Atsumi, S. (1981) Localization of surface and internal receptors in developing fast and slow muscles of the chick embryo. Dev. Biol. 86: 122-135.

Bauer, H. C., M. P. Daniels, P. A. Pudimat, L. Jacques, H. Sugiyama, and C. N. Christian (1981) Characterization and partial purification of a neuronal factor which increases acetylcholine receptor aggregation on cultured muscle cells. Brain Res. 209: 395-404.

Bennett, M. R., and A. G. Pettigrew (1974) The formation of synapses in striated muscle during development. J. Physiol. (Lond.) 241: 515-545.

Berg, D. K., and Z. W. Hall (1975) Loss of $\alpha$-bungarotoxin from junctional and extrajunctional acetylcholine receptors in rat diaphragm muscle in vivo and in organ culture. J. Physiol. (Lond.) 252: 771-789.

Betz, W., and B. Sakmann (1973) Effects of proteolytic enzymes on function and structure of frog neuromuscular junctions. J. Physiol. (Lond.) 230: 673-688.

Bevan, S., and J. H. Steinbach (1977) The distribution of $\alpha$ bungarotoxin binding sites on mammalian skeletal muscle developing in vivo. J. Physiol. (Lond.) 267: 195-213.

Birks, R. I. (1966) The fine structure of motor nerve endings at frog myoneural junctions. Ann. N. Y. Acad. Sci. 135: 8-26.

Bixby, J. L. (1981) Ultrastructural observations on synapse elimination in neonatal rabbit skeletal muscle. J. Neurocytol. 10: $81-100$.

Bixby, J. L., and D. C. van Essen (1979) Regional differences in the timing of synapse elimination in skeletal muscles of the neonatal rabbit. Brain Res. 169: 275-286.

Bloch, R. J., and J. H. Steinbach (1981) Reversible loss of acetylcholine receptor clusters at the developing rat neuromuscular junction. Dev. Biol. 81: 386-391.

Braithwaite, A. W., and A. J. Harris (1979) Neural influence on acetylcholine receptor clusters in embryonic development of skeletal muscles. Nature 279: 549-551. 
Brown, M. C., J. K. S. Jansen, and D. C. van Essen (1976) Polyneuronal innervation of skeletal muscle in new-born rats and its elimination during maluration. J. Physiol. (Lond.) 261: $387-422$.

Burden, S. (1977) Development of the neuromuscular junction in chick embryo: The number, distribution, and stability of acetylcholine receptors. Dev. Biol. 57: 317-329.

Burden, S. J., P. B. Sargent, and U. J. McMahan (1979) Acetylcholine receptors in regenerating muscle accumulate at original synaptic sites in the absence of the nerve. J. Cell Biol. 82: 412-425.

Bursztajn, S., and G. D. Fischbach (1980) Accumulation of coated vesicles bearing $\alpha$-BTX binding sites in brain treated myotubes. Soc. Neurosci. Abstr. 6: 358.

Cartaud, J., A. Sobel, A. Rousselet, P. F. Devaux, and J. -P. Changeux (1981) Consequences of alkaline treatment for the ultrastructure of the acetylcholine-receptor-rich membranes from Torpedo marmorata electric organ. J. Cell Biol. 90: 418-426.

Christian, C. N., M. P. Daniels, H. Sugiyama, Z. Vogel, L. Jacques, and P. G. Nelson (1978) A factor from neurons increases the number of acetylcholine receptor aggregates on cultured muscle cells. Proc. Natl. Acad. Sci. U. S. A. 75: 40114015.

Dennis, M. J. (1981) Development of the neuromuscular junction: Inductive interactions between cells. Annu. Rev. Neurosci. 4: 43-68

Dennis, M. J., L. Ziskind-Conhaim, and A. J. Harris (1981) Development of neuromuscular junctions in rat embryos. Dev. Biol. 81: 266-279.

Diannond, J., and R. Miledi (1962) A study of foetal and newborn rat muscle fibers. J. Physiol. (Lond.) 162: 393-408.

Ellisman, M. H., J. E. Rash, L. A. Staenelin, and K. R. Porter (1976) Studies of excitable membranes. II. A comparison of specializations at neuromuscular junctions and non-junctional sarcolemmas of mammalian fast and slow twitch muscle fibers. J. Cell Biol. 68: 752-774.

Fambrough, D. M., and P. N. Devreotes (1978) Newly synthesized acetycholine receptors are located in the Golgi apparatus. J. Cell Biol. 76: 237-244.

Fertuck, H. C., and M. M. Salpeter (1974a) Localization of acetylcholine receptor by ${ }^{125} \mathrm{I}$-labeled $\alpha$-bungarotoxin binding at mouse motor endplates. Proc. Natl. Acad. Sci. U. S. A. 71: 1376-1378.

Fertuck, H. C., and M. M. Salpeter (1974b) Sensitivity in electron microscope autoradiography for $\mathrm{I}^{125}$. J. Histochem. Cytochem. 22: 80-87.

Fertuck, H. C., and M. M. Salpeter (1976) Quantitation of junctional and extrajunctional acetylcholine receptors by electron microscope autoradiography after ${ }^{125} \mathrm{I}$ - $\alpha$-bungarotoxin binding at mouse neuromuscular junctions. J. Cell Biol. 69: $144-158$.

Fischbach, G. D., and S. M. Schuetze (1980) A postnatal decrease in acetylcholine channel open time at rat endplates. J. Physiol. (Lond.) 303: 125-139.

Frank, E., and G. D. Fischbach (1977) Acetylcholine receptors accumulate at newly formed nerve-muscle synapses in vitro. In Cell and Tissue Interactions, J. W. Lash and M. M. Burger, eds., pp. 285-291, Raven Press, New York.

Frank, E., and G. D. Fischbach (1979) Early events in neuromuscular junction formation in vitro. J. Cell Biol. 83: 143158.

Gauthier, G. F., S. Lowey, P. A. Benfield, and A. W. Hobbs (1982) Distribution and properties of myosin isozymes in developing avian and mammalian skeletal muscle fibers. J. Cell Biol. 92: 471-484.

Hall, Z. W., and R. B. Kelly (1971) Enzymatic detachment of endplate acetylcholinesterase from muscle. Nature New Biol.
232: $62-63$.

Heuser, J. E., T. S. Reese, and D. M. D. Landis (1974) Functional changes in frog neuromuscular junctions studied with freeze-fracture. J. Neurocytol. 3: 109-131.

Hourani, B. T., B. F. Lorain, M. P. Henkart, R. L. Carter, V. Marchesi, and G. D. Fischbach (1974) Acetylcholine receptors of cultured muscle cells demonstrated with ferritin- $\alpha$ bungarotoxin conjugates. J. Cell Sci. 16: 473-479.

Jacob, M., and T. Lentz (1979) Localization of acetylcholine receptors by means of horseradish peroxidase- $\alpha$-bungarotoxin during formation and development of the neuromuscular junction in the chick embryo. J. Cell Biol. 82: 195-211.

Jessell, T. M., R. E. Siegel, and G. D. Fischbach (1979) Induction of acetylcholine receptors on cultured skeletal muscle by a factor extracted from brain and spinal cord. Proc. Natl. Acad. Sci. U. S. A. 76: 5397-5401.

Kelly, A. M., and S. I. Zacks (1969) The fine structure of motor endplate myogenesis. J. Cell Biol. 42: 154-169.

Kelly, S. S. (1978) The effect of age on neuromuscular transmission. J. Physiol. (Lond.) 274: 51-62.

Korneliussen, H., and J. K. S. Jansen (1976) Morphological aspects of the elimination of polyneuronal innervation of skeletal muscle fibres of newborn rats. J. Neurocytol. 5: 591604 .

Land, B. R., T. R. Podleski, E. E. Salpeter, and M. M. Salpeter (1977) Acetylcholine receptor distribution on myotubes in culture correlated to acetylcholine sensitivity. J. Physiol. (Lond.) 269: 155-176.

Land, B. R., E. E. Salpeter, and M. M. Salpeter (1980) Acetylcholine receptor site density affects the rising phase of miniature endplate currents. Proc. Natl. Acad. Sci. U. S. A. 77: 3736-3740

Landmesser, L. T., and D. G. Morris (1975) The development of functional innervation in the hind limb of the chick embryo. J. Physiol. (Lond.) 249: 301-326.

Lee, C. Y., S. L. Chang, S. T. Kau, and S.-H. Luh (1972) Chromatographic separation of the venom of Bungarus mul. ticinctus and characterization of its components. J. Chromatogr. 72: 71-82.

Loring, R. H., and M. M. Salpeter (1978) ${ }^{125} \mathrm{I}-\alpha$-bungarotoxin binding to denervated muscle: A survey study using light and EM autoradiography. Soc. Neurosci. Abstr. 4: 604.

Loring, R. H., S. W. Jones, J. A. Matthews-Bellinger, and M. M. Salpeter (1982) ${ }^{125} \mathrm{I}-\alpha$-bungarotoxin: The effect of radiodecomposition on specific activity. J. Biol. Chem. 257: 1418 1423.

Matthews-Bellinger, J. A., and M. M. Salpeter (1978) Distribution of acetylcholine receptors at frog neuromuscular junctions with a discussion of some physiological implications. J. Physiol. (Lond.) 279: 197-213.

Matthews-Bellinger, J. A., and M. M. Salpeter (1979) Distribution of acetylcholine receptors in developing and dystrophic mouse neuromuscular junctions. Soc. Neurosci. Abstr. 5: 485.

McLean, I. W., and R. K. Nakane (1974) Periodate-lysineparaformaldehyde fixative: A new fixative for immunoelectron microscopy. J. Histochem. Cytochem. 22: 1077-1083.

McMahan, U. J., J. R. Sanes, and L. M. Marshall (1978) Cholinesterase is associated with the basal lamina at the neuromuscular junction. Nature 271: 172-174.

Michelson, A. M., E. S. Russell, and P. J. Harman (1955) Dystrophia muscularis: A hereditary primary myopathy in the house mouse. Proc. Natl. Acad. Sci. U.S.A. 41: 1079-1084.

Michler, A., and B. Sakmann (1980) Receptor stability and channel conversion in the subsynaptic membrane of the developing mammalian neuromuscular junction. Dev. Biol. 80: $1-7$.

Nakajima, Y., Y. Kidokoro, and F. G. Klier (1980) The devel- 
opment of functional neuromuscular junctions in vitro: An ultrastructural and physiological study. Dev. Biol. 77: 52-72.

O'Brien, R. A. D., A. J. C. Östberg, and G. Vrbová (1978) Observations on the elimination of polyneuronal innervation in developing mammalian skeletal muscle. J. Physiol. (Lond.) 282: 571-582.

Padykula, H. A., and G. T. Gauthier (1970) The ultrastructure of the neuromuscular junctions of mammalian red, white and intermediate skeletal muscle fibers. J. Cell Biol. 46: 27-41.

Podleski, T. R., D. Axelrod, P. Ravdin, I. Greenberg, M. M. Johnson, and M. M. Salpeter (1978) Nerve extract induces increase and redistribution of acetylcholine receptors on cloned muscle cells. Proc. Natl. Acad. Sci. U. S. A. 75: 20352039.

Podleski, T. R., S. Nichols, P. Ravdin, and M. M. Salpeter (1979) Cloned myogenic cells during differentiation: Membrane biochemistry and fine-structural observations. Dev. Biol. 68: 239-258.

Porter, C. W., and E. A. Barnard (1975) The density of cholinergic receptors at the endplate postsynaptic membrane: Ultrastructural studies in two mammalian species. J. Membr. Biol. 20: 31-49.

Rash, J. E., C. S. Hudson, and M. H. Ellisman (1978) Ultrastructure of acetylcholine receptors at the mammalian neuromuscular junction. In Cell Membrane Receptors for Drugs and Hormones: A Multidisciplinary Approach, R. W. Straub and L. Bolis, eds., pp. 47-68, Raven Press, New York.

Redfern, P. A. (1970) Neuromuscular transmission in new-born rats. J. Physiol. (Lond.) 209: 701-709.

Rees, R. P. (1978) Inclusion in coated vesicle membrane as the transport mechanism for acetylcholine receptor molecules in isolated cultured sympathetic neurons. J. Cell Biol. 79: 99a.

Rees, R. P., M. B. Bunge, and R. P. Bunge (1976) Morphological changes in the neuritic growth cone and target neuron during synaptic junction development in culture. J. Cell Biol. 68: 240-263.

Reiness, C. G., and Z. W. Hall (1981) The developmental change in immunological properties of the acetylcholine receptor in rat muscle. Dev. Biol. 81: 321-331.

Reiness, C. G., and C. B. Weinberg (1981) Metabolic stabilization of acetylcholine receptors at newly formed neuromuscular junctions in rat. Dev. Biol. 84: 247-254.

Rosenthal, J., and P. S. Taraskevich (1977) Reduction of multiaxonal innervation at the neuromuscular junction of the rat during development. J. Physiol. (Lond.) 270: 299-310.

Rubenstein, N. A., and.A. M. Kelly (1981) Development of muscle fiber specialization in the rat hind limb. J. Cell Biol. 90: 128-144.

Sakmann, B., and H. R. Brenner (1978) Change in synaptic channel gating during neuromuscular development. Nature 276: 401-402.

Salpeter, M. M. (1967) Electron microscope autoradiography as a quantitative tool in enzyme cytochemistry. I. The distribution of acetylcholinesterase at motor endplates of a vertebrate twitch muscle. J. Cell Biol. 32: 379-389.

Salpeter, M. M. (1981) High resolution autoradiography. In
Techniques in the Life Sciences: Techniques in Cellular Physiology, Part I: Physiology, vol. P1/I, p106, pp. 1-45, Elsevier-North Holland, County Clare, Ireland.

Salpeter, M. M., and L. Bachmann (1964) Autoradiography with the electron microscope. A procedure for improving resolution, sensitivity and contrast. J. Cell Biol. 22: 169-477.

Salpeter, M. M., and L. Bachmann (1972) High resolution shadowing. In Principles and Techniques of Electron Microscopy, Biological Applications, M. A. Hayat, ed., Vol. 2, pp. 197-217, Van Nostrand Reinhold, New York.

Salpeter, M. M., L. Bachmann, and E. E. Salpeter (1969) Resolution in electron microscope radioautography. J. Cell Biol. 41: 1-20.

Salpeter, M. M., H. Plattner, and A. W. Rogers (1972) Quantitative assay of esterases in endplates of mouse diaphragm by electron microscope autoradiography. J. Histochem. Cytochem. 20: 1059-1068.

Salpeter, M. M., H. C. Fertuck, and E. E. Salpeter (1977) Resolution in electron microscope autoradiography. III. Iodine-125, the effect of heavy metal staining, and a reassessment of critical parameters. J. Cell Biol. 72: 161-173.

Salpeter, M. M., S. Spanton, K. Holley, and T. R. Podleski (1982) Brain extract causes acetylcholine receptor distribution and finestructural changes which mimic some early events at developing neuromuscular junctions. J. Cell Biol. 93: 417-425.

Sato, T. (1968) A modified method for lead staining thin sections. J. Electron Microsc. 17: 158-159.

Steinbach, J. H. (1981) Developmental changes in acetylcholine receptor aggregates at rat skeletal neuromuscular junctions. Dev. Biol. 84: 267-276.

Steinbach, J. H., J. H. Merlie, S. Heinemann, and R. Bloch (1979) Degradation of junctional and extrajunctional acetylcholine receptors by developing rat skeletal muscle. Proc. Natl. Acad. Sci. U. S. A. 76: 3547-3551.

Sytkowski, A. J., Z. Vogel, and M. W. Nirenberg (1973) Development of acetylcholine receptor clusters on cultured muscle cells. Proc. Natl. Acad. Sci. U. S. A. 70: 270-274.

Teräväinen, H. (1968) Development of the myoneural junction in the rat. Z. Zellforsch. 87: 249-265.

Theiler, K. (1972) The House Mouse, Springer Verlag, New York.

Tweedle, C. D., and K. E. Stephens (1981) Development of complexity in motor nerve endings at the rat neuromuscular junction. Neuroscience 6: 1657-1662.

Vogel, Z., and M. P. Daniels (1976) Ultrastructure of acetylcholine receptor clusters on cultured muscle fibers. J. Cell Biol. 69: 501-507.

Vogel, Z., M. P. Daniels, M. Vigny, H. C. Bauer, P. Sonderegger, and C. N. Christian (1981) The effect of laminin, a basement membrane protein, on the cell surface aggregation of acetylcholine receptors of culture myotubes. Soc. Neurosci. Abstr. 7: 143.

Weldon, P. R., and M. W. Cohen (1979) Development of synaptic ultrastructure at neuromuscular contacts in an amphibian cell culture system. J. Neurocytol. 8: 239-259. 